UDC 94(477.83/.86=411.16)“1914/1915"

DOI10.24919/2519-058X.18.226532

\title{
Andrii SHCHEHLOV
}

PhD (History), Army Scientific Center Leading Researcher, Hetman Petro Sahaidachnyi National Army Academy, 32 Heroiv Maidanu Street, Lviv, Ukraine, postal code 79012 (deep_in_faith@ukr.net)

ORCID: 0000-0002-6484-0864

\section{Oleksandra MELNYK}

PhD (Economics), Docent of the Department of Humanities, Hetman Petro Sahaidachnyi National Army Academy, 32 Heroiv Maidanu Street, Lviv, Ukraine, postal code 79012 (lmmlviv@gmail.com)

ORCID: 000-0003-3497-4148

\section{Андрій ЩЕГЛОВ}

кандидат історичних наук, провіднийнауковий співробітник Наукового иентру Сухопутних військ, Наиіональна академія Сухопутних військ імені гетьмана Петра Сагайдачного, вулиия Героїв Майдану, 32, м. Львів, Україна, індекс 79012 (deер_in_faith@ukr.net)

\section{Олександра МЕЛЬНИК}

кандидат економічних наук, доцент кафедри гуманітарних наук, Національна академія Сухопутних військ імені гетьмана Петра Сагайдачного, вулиия Героїв Майдану, 32, м. Львів, Украӥна, індекс 79012 (v.vyzdryk@gmail.com)

Bibliographic Description of the Article: Shchehlov, A. \& Melnyk, O. (2021). The Situation of the Jewish Minority during the Russian Occupation of Eastern Galicia in 1914 - 1915. Skhidnoievropeiskyi Istorychnyi Visnyk [East European Historical Bulletin], 18, 88-97. doi: 10.24919/2519-058X.18.226532

\section{THE SITUATION OF THE JEWISH MINORITY DURING THE RUSSIAN OCCUPATION OF EASTERN GALICIA IN 1914 - 1915}

\begin{abstract}
The purpose of the article - to analyze the situation, the state of affairs of the Jewish population of Eastern Galicia during World War I from August of 1914 till June of 1915. The methodology of the research: adherence to the principles of objectivity and historicism contributed to the elucidation of the preconditions, essence and consequences of the Russian administration activities during the occupation period concerning the Jewish community of Eastern Galicia. The scientific novelty consists in a comprehensive problem coverage of the civilian administration and military command attitude to the local population and national minorities; in the analysis of socio-political and economic processes on the eve and during the years of the Russian occupation administration, which has not been the subject of a special historical study. The attempt has been made to recreate the picture of political changes in the structure of Galician multinational society, where a social category emerged - the refugees. New archival materials have been introduced into scientific circulation, which allowed to generalize the situation of the Jewish community of Galicia during World War I. The Conclusions. The occupation of the Galician region by the Russian troops was accompanied by a violent policy against the local population and
\end{abstract}


national minorities of the region. The government's inaction led to mass looting and military violence against the Jews. Russia's anti-Jewish policy on the South-Western Front had a negative effect on the country's international image, creating additional obstacles for the country to obtain foreign loans. The policy of persecution of the Jewish population by the state led to the confrontation in the society, the creation of stereotypes ingrained in the public consciousness, where the Jews acted as enemies, traitors, moneylenders, speculators, who were accused of all internal and military miscalculations of the Empire.

Key words: Jewish minority, occupation, Eastern Galicia, the Russian Empire, World War I.

\title{
СТАНОВИЩЕ ЄВРЕЙСЬКОЇ МЕНШИНИ ПІД ЧАС РОСІЙСЬКОї ОКУПАЦІї СХІДНОї ГАЛИЧИНИ В 1914 - 1915 pp.
}

\begin{abstract}
Анотація. Мета роботи - проаналізувати становище єврейського населення СхідноїГаличини в період Першої світової війни з серпня 1914 по червень 1915 рр. Методологія дослідження: дотримання принципів об'єктивності та історизму сприяло розкриттю передумов, сутності та наслідків діяльності російської адміністрації протягом усього окупачійного періоду щзодо єврейської спільноти Східної Галичини. Наукова новизна полягає у комплексному висвітленні проблеми ставлення цивільної адміністрації та військового командування до місцевого населення та національних меншин аналізі суспільно-політичних та економічних процесів напередодні та в роки російської окупаційної адміністрації, щзо донині не було предметом спеціального історичного дослідження. Зроблено спробу відтворити картину політичних змін у структурі галицького багатонаціонального суспільства, де з явилася сочіальна категорія - біжениі. Введено до наукового обігу нові архівні матеріали, щзо дозволили узагальнити становище єврейської спільноти Галичини у роки Першої світової війни. Висновки. Захоплення галицького краю російськими військами супроводжувалося насильницькою політикою до місчевого населення й національних меншин краю. Бездіяльність влади призводила до масових грабунків та проявів насильства з боку військових щзодо євреїв. Антиєврейська політика Росї̈ на Південно-Західному фронті негативно позначилася на міжнародному іміджі держави, щзо створювало додаткові перешкоди для отримання країною зовнішніх кредитів. Політика переслідування юдейського населення з боку держави призвела до конфронтації в суспільстві, породження стереотипів які закріпилися в суспільній свідомості, де євреї виступають як вороги, зрадники, лихварі, спекулянти, яких звинувачували у всіх внутрішньодержавних та військових прорахунках імперіі.
\end{abstract}

Ключові слова: єврейська меншина, окупаиія, Східна Галичина, Російська імперія, Перша Світова війна.

The Problem Statement. The course of World War I led to changes in the social structure of the society in Central and Eastern Europe. The majority of modern historical research concerns socio-political processes, military operations, the issues related to the resettlement of the population of Galicia, the activities of charitable organizations, superficially concerning the issue of refugees and the deportation of the Jewish population.

The Analysis of Recent Researches and Publications. We try to analyze the occupation policy of tsarist Russia in Galicia towards the regional Jewish minority, considering its position and the role of military command and civilian administration in the deportation of the Jews to Left-Bank Ukraine and the central provinces of the Russian Empire. The chronology of the study covers the period of 1914 - 1915. The researches of the following Ukrainian historians attract attention: Ya. Dashkevych, (Dashkevych, 2010), W. Melamed (Melamed, 1994), O. Reient (Reient, 2007), L. Zhvanko (Zhvanko, 2008), L. Bilous (Bilous, 2011), O. Serdiuk (Serdiuk, 2002), H. Seheda (Seheda, 2005), who analyzed superficially the situation of the national minorities of Eastern Galicia during World War I, involuntary resettlement and refugee problems were mainly considered in the context of the activities of charitable organizations related to the evacuation of the population of Galicia, Bukovyna and Volyn. The majority of 
the scientific researches is devoted to the study of military operations in Western Ukraine, the attitude of political parties and public organizations towards the Russian occupation of the region, coverage of socio-political and economic processes before and during the Great War. Of scientific interest is the collection of materials of the local press of that time and the memoirs of eyewitnesses of these events, the testimonies of prisoners, who were taken hostage, as well as the attitude of the Russian occupation administration to the local population and national minorities (Semeniv, 2018). In the field of modern Ukrainian historians, the coverage of the issue of deportation and refuge of the Jewish population of Galicia has not been analyzed properly. Among foreign scholars, the state and migration of Galician Jewry during the Great War were studied by: G. Ioffe (Ioffe, 2001), S. Nelipovich (Nelipovich, 2004, 2009), E. Lohr (Lohr, 2001), S. Goldin (Goldin, 2005), O. Prusin (Prusin, 2005) and the others.

Among modern Russian scientific research we can single out the monograph of O. Bakhturina (Bakhturina, 2000), in which the policy of the Russian Empire in Galicia in 1915 -1917 was characterized, in particular, superficially, the problem of refugees, "exiles", hostages. One of the latest is the monograph "The Jews and the Ukrainians: Millennium of Coexistence" (Magochii \& Petrovskyi-Shtern, 2018). The authors set the objective of dispelling mutual stereotypes and prejudices common both among the part of the Ukrainian society and certain groups of the Jews outside Ukraine regarding international relations in the region.

The purpose of the study is to analyze the policy of the Russian Empire towards the Jewish population of Eastern Galicia during World War I from August of 1914 till June of 1915.

The Basic Material Statement. Galician lands became the main arena in the Eastern Theater of War. The confrontation between the warring sides led to the economic destruction and the sustainable way of life destruction of the region's population. "This part of the region, as described by "The Dilo" newspaper, is now presented as if it were deserted; villages and whole forests have disappeared from the ground, and as far as the eye can see, only the black soil, plowed by trenches" (Dilo, (4), 1915). The policy of tsarist Russia towards the Ukrainian lands was determined by the principle of imperial centrism and the suppression of any manifestations of separatism.

After a final occupation of Galicia in September and Bukovyna in October 1914, the Russian authorities liquidated the Austrian authorities and began to form their own administrative system under the "Provisional Regulations on the Administration of the Regions of AustriaHungary under the Law of War". "The Provisional Military Governor-General of Galicia" was established (RSMHA, f. 2003, d. 1, c. 1, p. 54), headed by Count G. Bobrynsky, which included four provinces: Lviv, Ternopil, Przemyśl and Chernivtsi with the division into 56 counties. To control the attitude of the Galician population towards the Russian occupation authorities and to detect "the places of a hostile resistance", the "Provisional Gendarmerie Department under the Governor-General" was established, which was divided into 9 districts (RSMHA, f. 2003, d. 2. c. 539. pp. 9, 6-17).

The Russian occupation authorities included into the list of their "enemies" not only the Ukrainians, the Germans, but also the Jews, who, although were recognized as a separate nation, but without rights. The"settlement zone" continued to be applied to the Jews (the territory of a compact residence of the Jews in the Russian Empire, defined by the imperial government in order to prevent their penetration into the Greater Russian provinces to protect the Russian entrepreneurship from the Jewish rivalry, abolished only in February 1917). In support of these words, we can cite a memorandum to the Supreme Commanderin-Chief of the Russian troops from the Director of the Diplomatic Chancellery, M. Basili, 
who emphasized the hostility of the Jews to the Russian army, which was manifested in concealing food or selling it at speculative prices. It was noted that the Jews owned $35 \%$ of landlordism (Mezhdunarodnye otnosheniia, 1935, pp. 335-336, 337).

In his letter, General M. Bonch-Bruievych informed the Chief of Staff of the Russian Army, M. Yanushevych, that the Russian Empire was full of hostile deported subjects, who needed accurate registration, so that this hostile element could be completely eliminated after the war (Lohr, 2003). This fact one more time confirms the idea that anti-Semitism and xenophobia prevailed among the military leadership, as well as, among other highranking government officials. At the end of the XIXth - the beginning of the XXth centuries the Jewish national minority in the Russian Empire reached 5 million people, representing $4.16 \%$ of the total population (Natans, 2007, p. 208). Whereas at the beginning of the XXth century, in the Galician lands there lived more than 700 thousand of the Jews, which was respectively $-12.3 \%$ of the total population (Wrobel, 1994, p. 139).

Historically, the Jews were the subject to various legal restrictions in their place of residence and occupation in the Russian Empire. This fact caused the idea formation of an enemy of "a nation at war" (Lohr, 2001, p. 405). It should be noted that the legal insecurity of the Jews and persons belonging to other national minorities led to wrongful actions on the part of both the state and the common people, which led to interethnic conflicts.

At the end of 1914, in 1915, the Russian military joined the forced eviction of "hostile" people from the front line, which "was one of the first cases of a large-scale resettlement at the initiative of the state" (Bilous, 2011, pp. 69-70). At the same time, the Cossack army units took part in the pogroms of the Jewish estates from the beginning of the hostilities in Galicia and Bukovyna.

On September 7, 1914, the head of Rohatyn County informed the Governor of Lviv: "Everywhere in the county there is a picture of the complete destruction of landlords and Jewish estates, the property in these estates, if not looted, then destroyed. Cultivation and sowing of fields, as well as, harvesting are hampered by the lack of horses, vehicles confiscated first by the Austrian and then by our troops" (SALR, f. 907, d. 1, c. 33, pp. 2-3). Many owners of farms in Ternopil district, Stanislavshchyna and Lvivshchyna left their estates and were forced to migrate to the central territories of the Austrian Empire. These farms were looted and destroyed by the Russian troops "a crowd of soldiers headed (led - ed.) by the Cossacks, rushed, primarily, to the Jewish shops and abandoned apartments and the Russian officers not only allowed the looting, but even encouraged and participated in them" (Pid rosiiskym naizdom, 1915, p. 2). Thus, in the village of Mershenivka, Borshchiv district, V. Hert's filvarok was destroyed, the damage was at the price of 605000 crowns (CSHAUL, f. 191, d. 3, c. 14, pp. 17-19). In the village of Kudryntsi in the same county, Leiba Bartfeld's filvaroks were severely damaged. All residential buildings were burned to the ground and the damage was at the price of 103000 crowns (CSHAUL, f. 191, d. 3, c. 15, pp. 8-10).

There are many cases when during the retreat of the Austro-Hungarian troops the peasants also resorted to looting and arson of the estates of landlords and tenants. Thus, in September 1914, the estate of the landlady, A. Zaeman, in the village of Skomorohy Novi, Berezhany district, was destroyed (Diadychenko, 1967, p. 523).

M. Hankevych, Galician public and political figure, mocked the Russian politicians, who believed that the tsar was an ally of "Western European democracy", who headed a "liberation war" against "the German imperialism" to defend "culture and civilization". "... proof of a highly cultural mission - pogroms of the Jews have already taken place in Lviv. Leaders 
of tsarist troops allow peasants (Galician peasants), and even order, to plunder manors and Jewish shops and inns. Peasants, who do not want to follow the orders of the tsarist demagogues, are killed as friends of the Jews, as servants of the Austrian army" (Hankevych, 1915, p. 6). Thus, the army leadership had all the leverage to prevent and stop violence at the territory under its control, but did not do so.

The withdrawal of the Russian troops from Galicia in April 1915 led to the evacuation of the civilian population. The flow of refugees increased as the army moved further to the East. In order to streamline this process, the command of the South-Western Front authorized the governors of Podilsk and Volyn to deal with the problems of refugees, who were granted a loan of 100000 rubles (CSHAUK, f. 361, d. 1, c. 546, p. 35). The situation with refugees became an acute state problem, so the Russian Duma, in September of 1915, passed the law "On Meeting the Needs of Refugees". Refugees were those, who had left areas threatened by the enemy, or had already been occupied by the enemy, also evicted by order of military or civilian authorities from the area of the hostilities, natives of hostile to Russia states, with the exception of foreigners - the subjects of the German or Austro-Hungarian state, who were evicted from the war zone administratively under police supervision, who were not considered refugees (Zakony i rasporyazheniya o bezhencah, 1916, pp. 2, 3). In the Russian Empire, in addition to refugees, there was a separate category of deported Jews from Galicia, who were deported as "unreliable" (Holkvist, 1998, pp. 26-54).

According to the calculations of E. Volkov, a researcher, at the end of 1917 the number of refugees and immigrants from the western fronts of the Russian Empire was 7421000 people (Volkov, 1930, p. 72). Of this total, deported Jewish population was approximately from 500000 to 1 million (Lohr, 2001, p. 64). According to the data of T. Lazanska, the Ukrainian researcher, the number of Jewish immigrants from Eastern Galicia to the Russian Empire was 350 thousand people (Lazanska, 2009, p. 211). The Jews were often accused of spying for the Austrian troops and hiding defectors from the ranks of the Russian army or prisoners. This was, primarily, due to the desire of the population to resist the violent actions of the occupying power, looting and arbitrariness of regular army units, especially when the population lived near the front line. The Russian officials and the military command, in fact, blamed the Jews for all their troubles and defeats at the front, considering them, perhaps, Russia's greatest enemies (Yakhontov, 1926, p. 43).

Not only the occupation power but also the Russian intelligentsia was convinced of the treachery of Judaism. Illustrative in this respect is the opinion of the famous Russian lawyer, V. Maklakov, who was a defender of M. Beyliss at the trial of 1913, who emphasized the hostility of the Jews of Galicia towards the Russians (Ansky, 2002, p. 20).

Another legal restriction on Judaism was the ban on entry and free movement at the territory of Galicia, which was introduced in mid-February of 1915. Violators of GovernorGeneral G. Bobrynsky’s order were fined or imprisoned (Petrovych, 1915, pp. 114-115).

Administrative evictions were used for most people, whose stay in the province was considered "harmful" by the occupying authorities. Thus, before the loss of Sniatyn, the Russian troops captured "more than 3000 Jews, many of them women, children, the weak, and the elderly. It was a terrifying wave when a whole crowd of poor people, under a storm of whips and sabers, started to move to Zalishchyky. In Sniatyn there is still no news about their fate" (Ukrainske slovo, 1918, p. 3). The sporadic deportation of the Jewish population to the interior of Russia from the war zone began in January of 1915, and from May of 1915 the resettlement became widespread and lasted until September. 
According to the commander of the 11th Army, D. Shcherbachev, the expulsion of the Jewish population to the Russian Empire was economically impractical and dangerous, because they "spread... a contagion of both political and infectious nature...". Therefore, it was proposed to direct the flow of migrants to the border with Romania, but these proposals were not approved by the head of the Galicia-Bukovyna Governor-General G. Bobrynsky (CSHAUK, f. 361, d. 1, c. 674, pp. 78, 80).

Due to the aggravated situation on the South-Western Front in May of 1915, the deportation of the Jewish population also took place in the eastern Galician counties. Ternopil counties were overcrowded with the Jewish immigrants. They were under constant government surveillance. According to the report of Ternopil Governor I. Czartoryski, there were 300 deported Jews in Zbarazh County and 700 deported Jews in Skalat County. A similar situation was observed in Buchach, Chortkiv and other counties. In the newspaper "Dilo" it was written: “The Jews are terribly depressed..." (Rosyiane v Buchachy, 1915, p. 3)

The epidemiological situation was terrible in the region. The migration of large masses of the population, living in unsanitary conditions led to the spread of diseases such as typhus, dysentery, smallpox. Typhus spead "... in the communities of Hryniv, Polianka, Yablonytsa, Perekhresne, Stebne, Fereskulia of Kosiv district. There was lack of doctors and sanitary care" (Shcho diiet sia na Vkraini, 1915, p. 4).

It should be noted that the spread of tuberculosis, which affected up to a quarter of the Jewish population of Eastern Galicia, became threatening (Pohrebynska, 1997, p. 31).

It was common practice for well-known Jews to take a written undertaking not to leave, forcing them to be loyal to the authorities, otherwise they and their families were in danger of being imprisoned or executed, and their property could be confiscated by the end of the war (Lohr, 2001, p. 413). On September 3, the Russian troops entered Lviv. According to the occupation conditions of the city, 16 hostages had to be taken (four representatives: each from the Ukrainians, the Old Rusyns, the Poles and the Jews) and giving back weapons and ammunition by the population. The hostages were settled in separate rooms at the George Hotel. They were responsible for any anti-Russian actions (Organizatsyia ladu v misti Lvovi, 1914, pp. 1-3; V okupovanii terytorii, 1914. pp. 1-2).

Denunciations on the Jews for a reward, loyalty of the authorities and getting rid of rivalry were widespread.

Galician magazines of 1915 - 1916 published the lists of people deported by the Russians. Thus, in October 1915, the newspaper "Dilo" reported that the hostages, who had been taken to Kyiv from Lviv, appealed to the Supreme Command to return to their hometown, since the purpose for which they were taken was not topical, "because there are no more Russian troops in Lviv, there is no need to guarantee the loyal behaviour of the local population". Among the list of hostages we find the surnames of not only the Ukrainians and the Poles, but also famous and wealthy Jews: the rector of Lviv University, professor of physiology, Dr. Adolf Beck, a member of the Lawyer Association, the head of the Jewish community, Dr. Jacob Diamand, the chief physician of the eye clinic, the secretary of the Galician Chamber Maurice Oberlander, the printer Arthur Goldman, the merchants Isaac Shore, Samuel Pordes, Leo Goldman, Simon Feller, Bernard Brightman and Jacob Schreiber, manufacturers Solomon Goldfrucht, Moses Seckler, a landowner Michel Berl (Lvivski zakladnymy v Kyievi, 1915, p. 2). In Kyiv, the Jewish hostages lived in private houses and every morning they had to come to the police commissariats of the districts, in which they lived (Vyvezeni halychany, 1916, p. 3). 
In the lists of the Jews replaced from Stanislaviv, we find the surnames of the lawyer, Solomon Gelekhrtret; the owner of the printing house and bookstore, Eisig Weiderfeld; the railway conductor, Moses Imbermann; the students Adolf Rosenstraich, Leopold Pistreich and 27 merchants and intermediaries (Kurjer Lwowski, 1915, p. 5).

By Order of General M. Ivanov, Commander-in-Chief of the South-Western Front, at the beginning of 1915 the Jews were resettled to Left-Bank Ukraine in Poltava and Chernihiv provinces, partly in Kyiv, Kherson and Tavriya provinces, except the Crimea (Galperin, 2008). In addition, according to statistics, the percentage of the Jewish population from the occupied territories, in Russia the "settlement zone" was the following: 17\% - Central Russia, 14\% - Volga region, 7\% - the Urals and Siberia (Gatrell, 1999, p. 146).

As the situation at the front became more complicated, tsarist Russia's policy of the Jews resettlement to the East changed, allowing them to return home and stay out of the "settlement zone" if a ransom was paid for them, except for the territories, where regular military units were located according to the circular "Collection of Laws and Orders of the Government", which was published on August 21, 1915. It should be noted that very often local officials executed such orders at their own discretion (CSHAUK, f. 1010, d. 1, c. 59, pp. 207, 249, 281-283).

In the autumn of 1915, by Order of the Commander-in-Chief of the South-Western Front, a commission was organized, headed by General A. von Knorring, to deal with the cases of displaced persons and hostages. The commission clarified the state of detention, the place, verification of documents of residents displaced from Galicia, as well as the release of people, who had been resettled from the front line.

The occupation of Lviv by the Russian army, especially at the initial stage of the establishment of the administrative administration of Galicia and Bukovyna, gave impact to the Jewish pogroms. Violence was accompanied by looting and murder, and in the middle of September of 1914, 49 people were subjected to physical torture, the majority of them was the Jews, in addition, there was property confiscation, eviction and destruction of the Jewish houses. Such manifestations of violence by the Russian army took place in many cities and towns of the region (Petrovych, 1915, p. 115).

Moses Tanenbaum, the city secretary of Bukovyna town of Kitzman, wrote about the abuse of the Russian soldiers during the escort of the Jewish hostages to Galicia, “... the old men were beaten to blood by the Cossacks. They used to stab with spears when the Jews did not go quickly. Even children were not spared. [...] Some of the unfortunate fell from hunger and fatigue. [...] Cholera spread in Ulashkivtsi, Ozeriany, Tovste and Chortkiv, where the Jews resettled from Zalishchyky lived in huts and stables. [...] about 1000 died. [...] The Jews were taken to work forcibly, i.e., digging ditches along the banks of the Seret. [...] those people worked from 6 a. m. till 8 p.m. The Cossacks beat them incessantly. They were not allowed to eat. They were promised only 50 kopicks per day and even that sum was not paid. Violence was on the agenda. 30 women and girls were raped in Ulashkivtsi one day" (Ukrainske slovo, 1916, pp. 2-3). Marauders, looting of shops, smashing of windows and beating of the Jews were a mass phenomenon.

With the beginning of the hostilities in August of 1914 in Husiatyn County, the estate of the Jewish rabbi David Friedban was ruined completely, the Synagogue was severely damaged. There was no Jewish population, who remained in the town (Vanchura, etc., 2003, p. 81). The Cossack army was involved into almost all Jewish pogroms. The place, where the Cossacks appeared on the horizon, the local population expected violence there. 
The attitude of the Russian military administration towards the Jewish population at the occupied territories of Galicia and Bukovyna raised a wave of discontent in the international arena. The United States criticized Russia's policy, which affected the receiving of loans, interstate trade.

The Russian intelligentsia, such as M. Gorky, F. Sologub and other prominent figures, who founded the Society for the Study of the Jewish life, also opposed this Russian policy. The society aimed at acquainting the public with the life of the Jews and counteracting the anti-Semitic manifestations among the Russian society (Kel'ner, 2004, pp. 11-40).

Tsarist Russia's policy concerning the local population and national minorities on the South-West Front not only affected the front's military command negatively, but also weakened discipline among the Russian army, resulting in violence against the people of Eastern Galicia and failure on the front lines.

The Conclusions. The situation of the Jewish population is considered through the prism of the activities of the Russian military and civilian administrations in the occupied territories of Eastern Galicia. The war caused the displacement of the civilian population, which caused tension in the society and deterioration in relations among various national groups living in the area. The deportation of the Jews caused food crisis in some provinces (Chernihiv, Katerynoslav and Poltava), which led to the confrontation with the locals because the Jews were willing to work for lower wages. There was rivalry at the labour market. A social category emerged among the Jews - refugees, who were forced to leave their homes because of the hostilities.

The prospects for further research require a broad study of the Jewish issue in the context of the anti-Semitic policies of the Russian autocracy during World War I.

Acknowledgments. We express a sincere gratitude to all the members of the editorial board for consultations provided during the preparation of the article for publishing. Special thanks to Rector of Hetman Petro Sahaidachnyi National Army Academy for the support.

Funding. The authors received no financial support for the research, authorship, and publication of this article.

\section{BIBLIOGRAPHY}

Ansky, S. (2002). The Enemy at His Pleasure: A Journey through the Jewish Pale of Settlement during World War I. New York: Henry Holt and Company. 327 p. [in English]

Bakhturina, A. Yu. (2000). Politika Rossiyskoy imperii v Vostochnoy Galitsii v gody Pervoy mirovoy voyny [The policy of the Russian Empire in Eastern Galicia during World War I]. Moskva: AIRO-XX, 263 p. [in Russian]

Bilous, L. (2011). Deportatsiia yevreiskoho naselennia na terytorii Rosiiskoi imperii pid chas Pershoi svitovoi viiny [Deportation of the Jewish population at the territory Russian Empire during World War I]. Ukrains 'kyj istorychnyj zhurnal - Ukrainian Historical Journal, (2), 65-79. [in Ukrainian]

Dashkevych, Ya. (1990). Vzaiemovidnosyny mizh ukrainskym ta yevreiskym naselenniam u Skhidnii Halychyni (kin. XIX - poch. XX st.) [Relations between the Ukrainian and Jewish Population in Eastern Galicia (the end of the 19th - beginning of the 20th centuries)]. Ukrains'kyj istorychnyj zhurnal - Ukrainian Historical Journal, 10, 63-73 [in Ukrainian]

Derzhavnyi arkhiv Lvivskoi oblasti [State Archives of Lviv Region - SALR]

Diadychenko, V. A. (Ed.) (1967). Istoriia selianstva Ukrainskoi RSR. Vid naidavnishykh chasiv do Velykoi zhovtnevoi sotsialistychnoi revoliutsii (Vol. 1). Kyiv: NVP "Vydavnytstvo "Naukova dumka" NAN Ukrainy", 561 p. [in Ukrainian]

Dilo. (1915). Dilo, 30.01, 4. [in Ukrainian]

Galperin, B. D. (2008) Osobye zhurnaly Soveta ministrov Rossiyskoy imperii. 1909 - $1917 \mathrm{gg}$. 1915 god [Special journals of the Russian Empire Council of Ministers. 1909 - 1917. 1915]. Moskva: ROSSPEN, 715 p. [in Russian] 
Gatrell, P. (1999). A Whole Empire Walking. Refugees in Russia during World War I. Bloomington: Indiana University Press, 318 p. [in English]

Goldin, S. (2005). Deportatsii russkoy armiey evreev iz Kovenskoy i Kurlyandskoy guberniy (aprel - may 1915) [The Jews Deportation from the Kurland and Koven provinces by the Russian army (April-May 1915)]. Abstracts of Papers '05: Yevrei v menyayushchemsya mire. (pp. 260-265). Riga. [in Russian]

Hankevych, M. (1915). Pid teperishniu khvyliu [Under the present wave]. Visnyk Soiuza vyzvolennia Ukrainy - Bulletin of the Union of Liberation of Ukraine. Vienna, 21-22, 6. [in Ukrainian]

Holkvist, P. (1998) Russian catastrophe (1914 - 1921) in European context. Total mobilization and "population policy". Rossiya XXI, 11/12, 26-54. [in Russian]

Ioffe, G. Z. (2001). Vyselenie evreev iz prifrontovoy polosy v 1915 godu [The eviction of the Jews from the frontline in 1915]. Voprosy istorii-Questions of history, 9, 85-97. [in Russian]

Kel'ner, V. (2004) The Jewish Question and Russian Social Life During World War I. Russian Studies in History, 43, 11-40. [in English]

Kurjer Lwowski. (1915). Kurjer Lwowski [Lviv courier], 25.09, 5. [in Polish]

Lazanska, T. I. (2009). Stanovyshche bizhentsiv Ukrainy v roky Pershoi svitovoi viiny [The situation of refugees of Ukraine during World War I]. Problemy istorii Ukrainy XIX - XX st. Problems of the History of Ukraine in the 19th and 20th centuries, XVI, 196-240. [in Ukrainian]

Lohr, E. (2003). Nationalizing the Russian Empire: The Campaign Against Enemy Aliens during World War I. Harvard: Harvard University Press. 237 p. [in English]

Lvivski zakladnymy v Kyievi. (1915). Lvivski zakladnymy v Kyievi [Lviv people like hostages in Kiev]. Dilo, 29.10, 2. [in Ukrainian]

Magochii, P.-R. \& Petrovskyi-Shtern, Y. (2018). Yevrei ta ukraintsi : tysiacholittia spivisnuvannia [The Jews and the Ukrainians: millennia of coexistence]. Uzhhorod: Vydavnytstvo Valeriia Padiaka, 338 p. [in Ukrainian]

Melamed, V. (1994). Yevrei vo Lvove (XIII - pervaya polovina XX veka): sobytiya, obshchestvo, lyudi [The Jews in Lviv (XIII - first half of XX century): events, society, people.]. Lvov: TEKOP, 263 p. [in Russian]

Mezhdunarodnye otnosheniia. (1935). Mezhdunarodnye otnosheniia v epokhu imperializma: dokumenty iz arkhivov tsarskogo i Vremennogo pravitelstv 1878 - 1917 gg.: Seriia 3: $1914-1917$. Vol. 6: 5 avhusta 1914 g. - 13 yanvaria 1915 g. Ch. 1 [The International relations in the Era of Imperialism: documents from the archives of the Tsarist and the Provisional Governments 1878-1917: Series 3: 1914 - 1917. Vol. 6: August 5, 1914 - January 13, 1915 Part 1]. Moskva, 483 p. [in Russian]

Naselenie imperii. (1897). Naselenie imperii po perepisi 28-go yanvarya 1897 goda po uezdam [The population of the empire according to the census of January 28, 1897 by counties]. St. Petersburg, 30 p. [in Russian]

Natans, B. (2007). Za chertoy. Yevrei vstrechayutsya s pozdneimperskoy Rossiey [Behind the line. The Jews meet with late imperial Russia]. Moskva: ROSSPEN, 436 p. [in Russian]

Nelipovich, S. G. (2005) Nemtsy Varshavy v Pervoy mirovoy voyne $1914-1918$ gg. [The Germans of Warsaw in the First World War 1914 - 1918]. Abstracts of Papers '05: Rossiyskie nemtsy $v$ inonatsionalnom okruzhenii: problemy adaptatsii, vzaimovliyaniya, tolerantnosti. (pp. 261-279). Moskva. [in Russian]

Nelipovich, S. G. (2009). Voennoe vedomstvo i mennonity Rossii v Pervoy mirovoy voyne (1914 - 1918 gg.) [The War Department and Mennonites of Russia during the First World War (1914 - 1918)]. Abstracts of Papers '09: Etnicheskie nemtsy Rossii: Istoricheskiy fenomen "naroda v puti”. (pp. 85-103). Moskva. [in Russian]

Organizatsyia ladu v misti Lvovi. (1914). Organizatsyia ladu v misti Lvovi [Organization of order in Lviv]. Dilo, 2.09. 1-3. [in Ukrainian]

Petrovych, I. (1915). Halychyna pid chas rosiiskoi okupatsii: serpen 1914 - cherven 1915 [Galicia during the Russian occupation: August of 1914 - June 1915]. Viden': "Politychna biblioteka", 116 p. [in Ukrainian] 
Pid rosiiskym naizdom. (1915). Pid rosiiskym naizdom [Under Russian occupation]. Dilo. 25.12, 2. [in Ukrainian]

Pohrebynska, I. M. \& Hon, M. M. (1997). Yevrei v Zakhidnoukrainskii Narodnii Respublitsi (do problemy ukrainsko-ievreiskykh vzaiemyn) [Jews in the Western Ukrainian People's Republic (to the Problem of Ukrainian-Jewish Relations)]. Kyiv: NAN Ukrainy, Instytut natsionalnykh vidnosyn i politolohii, 86 p. [in Ukrainian]

Reient, O. (2007). Ukraina v Pershii svitovii viini: suchasni naukovo-metodolohichni aktsenty. Problemy istorii Ukrainy: fakty, sudzhennia, poshuky - Problems of Ukrainian history: facts, judgments, searches, 16, 88-103. [in Ukrainian]

Rosiiskyi derzhavnyi viiskovo-istorychnyi arkhiv [Russian State Military History Archive RSMHA]

Rosyiane v Buchachy. (1915). Rosyiane v Buchachy [The Russians in Buchach]. Dilo, 20.02, 3. [in Ukrainian]

Seheda, H.V. (2005). Ohliad dzherel ta literatury z problemy bizhentsiv v Ukraini u period Pershoi svitovoi viiny [Sources and literature on refugee problems in Ukraine during the First World War review]. Problemy istorii Ukrainy XIX - pochatku XX st. - History of Ukraine problems of the 19th-beginning of the 20th centuries, 9, 136-146. [in Ukrainian]

Semeniv, V. (Comps.) (2018). Moskovska okupatsiia Halychyny w 1914 - 1917 rr. v svidchenniakh suchasnykiv [Moscow's occupation of Galicia in 1914 - 1917 in the testimony of contemporaries]. Lviv: Apriori, 256 p. [in Ukrainian]

Serdiuk, O. V. (2002). Bizhenstvo v Ukraini pid chas Pershoi svitovoi viiny [Refugees in Ukraine during World War I]. Problemy istorii Ukrainy XIX - pochatku XX st. - History of Ukraine problems of the 19th-beginning of the 20th centuries, 4, 111-132. [in Ukrainian]

Shcho diiet sia na Vkraini. (1915). Shcho diiet sia na Vkraini [What is happening in Ukraine]. Dilo, 5.06, 4. [in Ukrainian]

Tsentralnyi derzhavnyi istorychnyi arkhiv Ukrainy u m. Lvovi [Central State Historical Archive of Ukraine in Lviv-CSHAUL]

Tsentralnyi derzhavnyi istorychnyi arkhiv Ukrainy, Kyiv [Central State Historical Archive of Ukraine, Kyiv - CSHAUK]

Ukrainske slovo. (1916). Ukrainske slovo [Ukranian word], 30.01, 2-3. [in Ukrainian]

Ukrainske slovo. (1918). Ukrainske slovo [Ukranian word], 08.08, 3. [in Ukrainian]

V okupovanii terytorii. (1914). V okupovanii terytorii [In the occupied territory]. Dilo, 5.09, 1-2. [in Ukrainian]

Vanchura, U., Ktytor, P. \& Melnychuk, Kh. (2003). Zemlia Ternopilska: turystychnyi putivnyk [Ternopil land: tourist guide]. Ternopil: Dzhura, 368 p. [in Ukrainian]

Volkov, Ye. Z. (1930). Dinamika narodonaseleniya SSSR za vosemdesyat let [The eighty years USSR population dynamics]. Moskva-Leningrad, 271 p. [in Russian]

Vyvezeni halychany. (1916). Vyvezeni halychany [Exported Halicians]. Dilo, 25.01, 3. [in Ukrainian]

Wrobel, P. (1994). The Jews of Galicia under Austrian-Polish Rule, 1867 - 1918. Austrian History Yearbook, XXV, 977-139. URL: http://www.jewishgen.org/ galicia/html/jews_of_galicia.pdf. [in English]

Yakhontov, A. N. (1926) Tyazhelye dni (Sekretnye zasedaniya Soveta ministrov 16 iyulya 2 sentyabrya 1915 g.) [Hard days (Secret meetings of the Council of Ministers July 16 - September 2, 1915)]. Arkhiv russkoy revolyutsii (XVIII). Berlin. [in Russian]

Zakony i rasporyazheniya o bezhencah. (1916). Zakony i rasporyazheniya o bezhencah [Refugee laws and regulations]. Vyp. 1. Moskva: Izdatel'stvo yuridicheskogo otdela Glavnogo komiteta Vserossijskogo soyuza gorodov. 2-e izd., dop., 103 p. [in Russian]

Zhvanko, L. M. (2008). Bizhenstvo Pershoi svitovoi viiny: istoriohrafiia problemy chy problemy istorii? [World War I refugees: a historiography of a problem or a problem of history?]. Istoriohrafichni doslidzhennia v Ukraini - Historiographic studies in Ukraine, 18, 380-392. [in Ukrainian]

The article was received on February 06, 2020.

Article recommended for publishing 17/02/2021. 